\title{
Agreements and Relationships of Market Actors for Mindanao Yellow Corn
}

\author{
Gigi B. Calica, Ph.D.*, Nancy L. Eleria, Ph.D. \\ Philippine Center for Postharvest Development and Mechanization (PHilMech), \\ CLSU Compound, Science City of Munoz, Nueva Ecija, Philippines \\ Graduate School, University of Santo Tomas, Espana, Manila, Philippines
}

\begin{abstract}
This study aimed to understand the relationships among the different actors involved in the handling practices of marketing yellow corn from Mindanao to Cebu and Manila focusing on the agreements and trust rating among the marketing actors. Descriptive analysis was employed in this study.

Results showed that the agreements among the marketing actors were all informal arrangements. Asymmetric information was evident on the farmers in the marketing chain because they were not properly informed by the other actors along the chain on the quality requirement of the end users resulting only to high production costs.

Results indicated that farmers trusted those they dealt with directly in the traditional system. Traders had some trust to both the farmers and processor/feedmillers because of the risks involved on his investment. Processors/integrators had complete trust with each other because they were the direct link from the source. Between the distributors and the feedmillers, trust was reciprocated because they were dependent to each other regarding the supply of corn.

In the bulk handing system, farmers and processor/shippers had some trust with each other because processor/shippers dealt with several farmers to accumulate stocks same as the farmer who could choose whom to sell his produce.

The frequent exchange of information and transparency of information creates trust in buyer-supplier relationships in the value chain thereby producing good quality corn. Moreover, aggressive promotion through trainings, publications and other media forms on the adoption of bulk handling system must be implemented by the government.
\end{abstract}

Key words: agreement, asymmetric information, trust, transparency, reciprocity, corn, marketing

\section{Introduction}

Corn (Zea mays L.) is the second most important crop after rice in the Philippines. Two types of corn are grown in the Philippines, white and yellow corn. Corn is consumed by around 20 percent of Filipinos as a staple in the form of milled white corn grits. The most dominant use of corn, predominantly yellow corn, is as feed ingredient.

At present, Mindanao yellow corn farmers produce low quality which commands low price in the market. To address this, problem, the government implemented projects on mechanical corn processing employing bulk handling which would produce good quality corn, reduced the postharvest losses and costs, and unload the farmers from the usual manual practice.

However, few farmers have been availing of the services of the processing center because of the reality that drying corn is free using sunlight. But with the climate change, sunlight is now not reliable in drying corn because it requires two to three days to dry the product. Three days are very critical for the quality of corn because this could lead to aflatoxin contamination.

With this technology at hand but few availed of its services, maybe something basic was overlooked to consider before implementing the project. Thus, this study is conducted with a general objective of 
understanding the relationships among the different actors involved in the traditional and bulk handling practices of marketing yellow corn from Mindanao to Cebu and Manila.

Specifically:

1. Establish the agreements set by the different chain actors in the traditional and bulk handling practices of marketing yellow corn from Mindanao to Cebu and Manila; and

2. Analyze the relationships among the different chain actors involved in the traditional and bulk handling practices of marketing yellow corn from Mindanao to Cebu and Manila.

\section{Materials and Methods}

Study sites

The study was conducted in Mindanao wherein yellow corn is produced while Cebu and Manila as the demand areas in addition to the Mindanao requirement.

Supply of corn generally comes from three regions in the Philippines, namely: Regions of Cagayan Valley, Northern Mindanao and SOCCSKSARGEN. Cagayan Valley is supplying the island of Luzon since it is located in the island. On the other hand, Northern Mindanao and SOCCSKSARGEN which are located in the island of Mindanao are supplying the area plus the island of Visayas wherein production of corn is very minimal. However, during lean months (September to November) when Luzon has shortage in supply of corn, Mindanao delivers the amount of corn needed in the area.

\section{Sampling Procedure}

Using stratified random sampling procedure, at 95 percent confidence level with 5 percent margin of error, around 344 farmer adopters and 175 traditional farmers were interviewed for the bulk handling and traditional practices, respectively.

On the other hand, wholesaler/traders, processors, and integrator respondents, were hundred percent interviewed from the list of the National Food Authority (NFA). Those identified by the farmer respondents from the interview who were not in the list of NFA were also considered.

Shippers and consignees were identified from the interviews of traders, processors and integrators. Moreover, Philippine Ports Authority (PPA) manifestos on corn shipping from Mindanao to Cebu and Manila were also consulted for additional respondents.

In addition, interviews were done to key informants such as heads and officials of government agencies, LGUs, NGOs, farmers' cooperatives officers, who were knowledgeable on the matter and involved on corn postharvest programs.

Focus group discussions were also conducted to validate the data gathered on the functions on the different processes undergone by the product, the product flow, relationships of the different actors, linkages, value changes along the chain, the flow of information and knowledge.

\section{Data analysis}

Descriptive analysis of data such as averages was used for the different agreements set by the actors involved in the chain.

Adopting the UNIDO trust rating done in 2009, key actors gave ratings of 1-4 to the other participating actors of the chain.

Trust rating 4 means he has complete trust with that particular actor

Trust rating 3 means he has some trust with that particular actor

Trust rating 2 means he has little trust with that particular actor

Trust rating 1 means he has no trust with that particular actor

Ratings made by the respondents were mainly based on the existing relationship and experiences during their marketing transactions with the particular actor being rated. Trust ratings were computed as: ratings for farmers by traders were summed up and divided it by the total number of trader-respondents.

Trust rating farmer $=\underline{\Sigma \text { (ratings of traders to farmer) }}$

Total no. of trader respondents

Trust rating $_{\text {farmer }}=\underline{\Sigma}$ (ratings of processors to farmer)

Total no. of processor respondents 
Trust rating $_{\text {farmer }}=\underline{\Sigma \text { (ratings of shipper to farmer) }}$

Total no. of shipper respondents

Trust rating farmer $=\underline{\Sigma}$ (ratings of distributor to farmer)

Total no. of distributor respondents

Trust rating farmer $=\underline{\Sigma \text { (sum of ratings of feedmiller to farmer) }}$

Total no. of feedmiller respondents

\section{Results and Discussion Agreements}

Asymmetric information arises when the market participants or agents do not have identical information. It provides incentive to better-informed agents to exploit their private information in manner that adversely affects less informed agents (Akerlof, 1970; Krugman, 2007). Two types of asymmetric information problems are of particular relevance: the moral hazard and the adverse selection.

Moral hazard problem is when one side cannot observe the actions of other side. The lack of one to one relationship between output and effort exerted prevents the trader from inferring amount of effort exerted by the farmer by observing output. On the other hand, adverse selection is problem is when the farmers have no information on the quality and type of agents, products or commodities. This may provide incentive to betterinformed agents to exploit their private information in a manner that adversely affects less informed marketing players in the chain.

Farmers' involvement in yellow corn production started from production activities to marketing of corn grains. They engaged in these activities to get good price for their produce even if they did not have enough knowledge and appropriate facilities to produce good quality corn. However, agreements among the marketing actors with the farmers were all informal arrangements. On the other hand, trader/processor/integrator who were more informed on the requirements of the end users repeats some of the activities (e.g. shelling to marketing) done by the farmer to comply with the requirements of the end-user. The key players with the least role in the chain were the distributor and the feedmiller.

Every activity in the postharvest system had accompanying agreement on the things to be done and the rate of payment. In the farm, farmers and the laborers had agreements to abide in their harvesting up to the storage activities. Traders, on the other hand, had their own agreements with the farmers. Usually, it dealt on the transporting of product from the farmer's place to their place. Corn quality requirement was also part of the agreement wherein price deductions based on the foreign matters and moisture contents were imposed as penalties. Notice that from among the actors involved in the traditional chain only between the distributor and feedmiller had a formal contract (Table 1).

As described by Calica and Eleria (2013) in Figure 1 key actors involved in the traditional chain were the farmer, trader/processor/integrator, shipper, consignee/distributor, and feedmiller. From among the chain actors, farmers were producing corn once a year and doing multi-tasking on the postharvest activities just to receive higher price for their produce. However, because of farmers' lack of knowledge on the requirements of the market and the postharvest facilities to produce good quality corn, trader/processor/integrator was repeating some of the activities the farmers engaged in particularly in shelling, drying, storage and marketing. The shipper, consignee/distributor and feedmiller performed very specific tasks such as shipping, distribution and feedmilling.

Table 1. Postharvest agreements set by the different key actors in Mindanao, traditional method, 2012

\begin{tabular}{|l|l|l|l|l|}
\hline ACTORS & \multirow{2}{*}{$\begin{array}{l}\text { POS THARVES T } \\
\text { INVOLVED }\end{array}$} & ACTIVITIES & \multicolumn{1}{|c|}{ AGREEMENTS } & \multirow{2}{*}{ REMARKS } \\
\cline { 3 - 5 } & Harvesting & $\begin{array}{l}\text { Harvesters picked and unhusked } \\
\text { corn before putting it inside } \\
\text { the sacks }\end{array}$ & P150/day & Owners offered snacks but optional \\
\hline Farmer & Hauling & $\begin{array}{l}\text { Laborers haul the corn packed in } \\
\text { bags from the farm to the nearest } \\
\text { road network or the shelling area }\end{array}$ & $\begin{array}{l}\text { P5-10/sack } \\
\text { depending on the } \\
\text { distance }\end{array}$ & $\begin{array}{l}<100 \text { meters was charged } \\
\text { the lowest. } \\
\text { Additional charge for } \\
>100 \mathrm{~m}\end{array}$ \\
\hline
\end{tabular}




\begin{tabular}{|c|c|c|c|c|}
\hline $\begin{array}{l}\text { Farmer/ } \\
\text { Trader/ } \\
\text { Processor/ } \\
\text { Integrator }\end{array}$ & Shelling & $\begin{array}{l}\text { Corn on cobs in sacks were poured } \\
\text { in the sheller's hopper and } \\
\text { corn grains were collected in a } \\
\text { can and packed it in sacks }\end{array}$ & P0.40/can & $\begin{array}{l}\text { Farmers wait for the availability of } \\
\text { shellers in the area }\end{array}$ \\
\hline $\begin{array}{l}\text { Farmer/ } \\
\text { Trader/ } \\
\text { Processor/ } \\
\text { Integrator }\end{array}$ & Drying & $\begin{array}{l}\text { Laborers hauled the corn in sacks } \\
\text { and poured on a pavement to dry } \\
\text { it down to } 13-14 \% \text { MC. }\end{array}$ & P6/sack & $\begin{array}{l}\text { Regardless of the number } \\
\text { of day s to dry corn }\end{array}$ \\
\hline $\begin{array}{l}\text { Farmer/ } \\
\text { Trader/ } \\
\text { Processor/ } \\
\text { Integrator }\end{array}$ & Storing & $\begin{array}{l}\text { Laborers stacked corn in sacks } \\
\text { inside the warehouse or room or } \\
\text { the space designated by the } \\
\text { farmer to pile the sacks of corn }\end{array}$ & $\mathrm{P} 1.50 /$ move & Usually 2 moves \\
\hline $\begin{array}{l}\text { Farmer/ } \\
\text { Trader/ } \\
\text { Processor/ } \\
\text { Integrator }\end{array}$ & Transporting & $\begin{array}{l}\text { Traders usually visited the farmer } \\
\text { at his place to negotiate and pick- } \\
\text { up the product from the place } \\
\text { In times when farmers were the } \\
\text { one to market, transport } \\
\text { cost would be shouldered by } \\
\text { the farmer }\end{array}$ & $\begin{array}{l}\text { free } \\
\text { P1/sack }\end{array}$ & $\begin{array}{l}\text { Free of charge within } 50 \\
\text { kilometer radius } \\
>50 \text { kilometer radius a minimal } \\
\text { fee was imposed } \\
\\
\text { Pay ment for the fare using } \\
\text { tricycle or jeepney }\end{array}$ \\
\hline $\begin{array}{l}\text { Processor/ } \\
\text { Trader/ } \\
\text { Processor/ } \\
\text { Integrator }\end{array}$ & Marketing & $\begin{array}{l}\text { Corn must be free from } \\
\text { foreign matters and with }<14 \% \\
\text { MC }\end{array}$ & Prevailing price & $\begin{array}{l}\text { Failure to meet the requirements of } \\
\text { the traders, } \\
1-3 \% \text { deductions in price or weight } \\
\text { would be imposed. } \\
\text { If both requirements were } \\
\text { not met whichever deduction } \\
\text { is higher would be imposed }\end{array}$ \\
\hline Shipper & Shipping & Shipping product from port to port & Prevailing shipping rates & Manila and Cebu destinations \\
\hline Distributor & Trucking & Distribution of products to end-users & Contract out & Manila and Cebu destinations \\
\hline Feedmiller & Feedmilling & Process corn grains to feeds & $\begin{array}{l}\text { Terms of payment } \\
\text { agreed upon between } \\
\text { parties }\end{array}$ & $\begin{array}{l}\text { Feedmillers could impose reduction } \\
\text { in price or rejection of delivery of } \\
\text { product was non-compliant }\end{array}$ \\
\hline
\end{tabular}

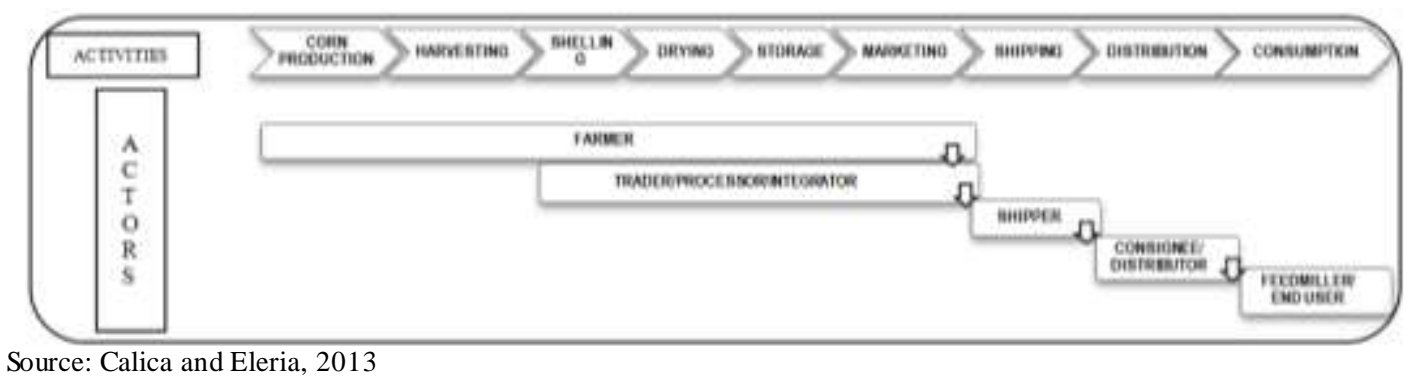

Figure 1. Yellow corn grain value chain activities and actors' role, traditional method, Mindanao to Manila and Cebu, 2012

In the bulk handling system, the farmer and the laborers agreed to pick up and haul the produce from the farm to the nearest road network. The processor would pick up the produce from the farm free of charge if within 50 kilometer radius. Outside of this, additional $\mathrm{PhP0} .20 / \mathrm{kg}$ would be charged. Moreover, the processor would be in charged of processing the corn from cob drying, shelling and grain drying and loading it to the 20footer container vans using flexible hose and transport it to the pier. The shippers would be the ones to ship the container vans of corn grains to its destination, Manila and Cebu, and delivered it to the feedmillers/end users. The feedmillers preferred their product delivered to them. However, non-compliance with their quality requirements would mean price reduction or rejection of the delivery (Table 2).

Calica and Eleria (2013) revealed that farmers practicing bulk handling were better-off when they concentrated more on producing corn by planting two to three times a year. Processors absorbed the activities unloaded from the farmers while shipper performed dual function, as a shipper and distributor. The key players with the least role in the chain were the distributor and the feedmiller (Figure 2). 
Feedmillers interviewed confirmed that corn grains from the processing centers were of good quality however it could not meet their volume requirement due to low supply and capacity of the center. Quality output of corn grains from the processing center showed that they were not exposed to foreign matters and prolonged drying activities that prevented aflatoxin contamination.

\section{Relationships}

In collaborative inter-enterprise relationships, trust is considered as powerful commercial asset (Svensson, 2005) mostly because a lack of trust can have severe cost implications. If business partners can trust each other, contractual arrangements may be reduced or avoided, implying lower costs and thus securing competitive advantage (Chiles and McMackin, 1996). Chen (2000) shows that trust is widely relied on in transactions involving relatively low monetary value and considerable resources are sometimes used in structuring contracts when the transactions involved have relatively high monetary value.

Table 2. Postharvest agreements set by the different key actors in Mindanao, bulk handling system, 2012

\begin{tabular}{|c|c|c|c|c|}
\hline \multirow{2}{*}{$\begin{array}{l}\text { ACTORS } \\
\text { INVOLVED }\end{array}$} & \multirow{2}{*}{$\begin{array}{l}\text { POSTHARVEST } \\
\text { ACTIVITIES }\end{array}$} & \multicolumn{2}{|l|}{ AGREEMENTS } & \multirow{2}{*}{ REMARKS } \\
\hline & & Activities & Payment & \\
\hline Farmer & Harvesting & $\begin{array}{l}\text { Harvesters picked and unhusked corn } \\
\text { before putting it inside the sacks }\end{array}$ & 150/day & $\begin{array}{l}\text { Owners offered } \\
\text { snacks but optional }\end{array}$ \\
\hline Processor & Hauling & $\begin{array}{l}\text { Laborers haul the corn packed in bags from } \\
\text { the farm to the processing center }\end{array}$ & $\begin{array}{l}\text { Free } \\
\mathrm{P} 0.20 / \mathrm{kg}\end{array}$ & $\begin{array}{l}<50 \text { kilometers is free } \\
>50-100 \text { kilometers }\end{array}$ \\
\hline Processor & $\begin{array}{l}\text { Cob drying, } \\
\text { Shelling } \\
\text { to Drying }\end{array}$ & $\begin{array}{l}\text { Corn on cobs in sacks are poured in the cob } \\
\text { dryer to dry from initial MC to } 18 \% \text { then } \\
\text { shell, grain dry to } 14 \% \mathrm{MC} \text { and temper the } \\
\text { corn. Through the use of flexible hose } \\
\text { connected to the spout of the grain dryer, cor } \\
\text { grains are poured } \\
\text { to the container vans ready for transporting th } \\
\text { pier. }\end{array}$ & $\mathrm{P} 1.75 / \mathrm{kg}$ & $\begin{array}{l}\text { A } 20 \text { footer container } \\
\text { van could only be } \\
\text { loaded of maximum } \\
\text { of } 20 \mathrm{MT}\end{array}$ \\
\hline Processor & $\begin{array}{l}\text { Transporting/ } \\
\text { Trucking }\end{array}$ & $\begin{array}{l}20 \text { footer container vans with } 20 \text { MT corn } \\
\text { grain load and transported to the pier }\end{array}$ & $\mathrm{P} 0.80-1 / \mathrm{kg}$ & $\begin{array}{l}\text { Depending on the } \\
\text { distance from the } \\
\text { source to pier. }\end{array}$ \\
\hline \multirow[t]{2}{*}{$\begin{array}{l}\text { Shipper/ } \\
\text { Distributor }\end{array}$} & Shipping & $\begin{array}{l}20 \text { footer container vans to be shipped } \\
\text { should be in the designated place in the pier1 } \\
\text { day before the scheduled } \\
\text { departure }\end{array}$ & $\begin{array}{l}\mathrm{P} 0.72 / \mathrm{kg} \\
\mathrm{P} 0.80 / \mathrm{kg}\end{array}$ & $\begin{array}{l}\text { Cebu destination } \\
\text { Manila destination }\end{array}$ \\
\hline & Trucking & $\begin{array}{l}20 \text { footer container vans from the pier to its } \\
\text { destination would be transported } \\
\text { only by the authorized trucking } \\
\text { company of PPA }\end{array}$ & $\begin{array}{l}\mathrm{P} 0.20 / \mathrm{kg} \\
\mathrm{P} 0.70-1 / \mathrm{kg}\end{array}$ & $\begin{array}{l}\text { Cebu } \\
\text { Manila to Batangas }\end{array}$ \\
\hline $\begin{array}{l}\text { Feedmiller/ } \\
\text { End-user }\end{array}$ & Marketing & $\begin{array}{l}\text { Must comply with the quality requirements } \\
\text { (free of foreign matters } \\
\text { and with }<14 \% \mathrm{MC} \text { ); to be subjected } \\
\text { to feedmillers' physical analysis }\end{array}$ & $\begin{array}{l}\text { Depends on the } \\
\text { terms of payment } \\
\text { agreed upon } \\
\text { between the seller } \\
\text { and the feedmiller }\end{array}$ & $\begin{array}{l}\text { Non- compliance on the } \\
\text { requirement, feedmillers } \\
\text { could impose reduction } \\
\text { in price or rejection of } \\
\text { the delivery }\end{array}$ \\
\hline
\end{tabular}

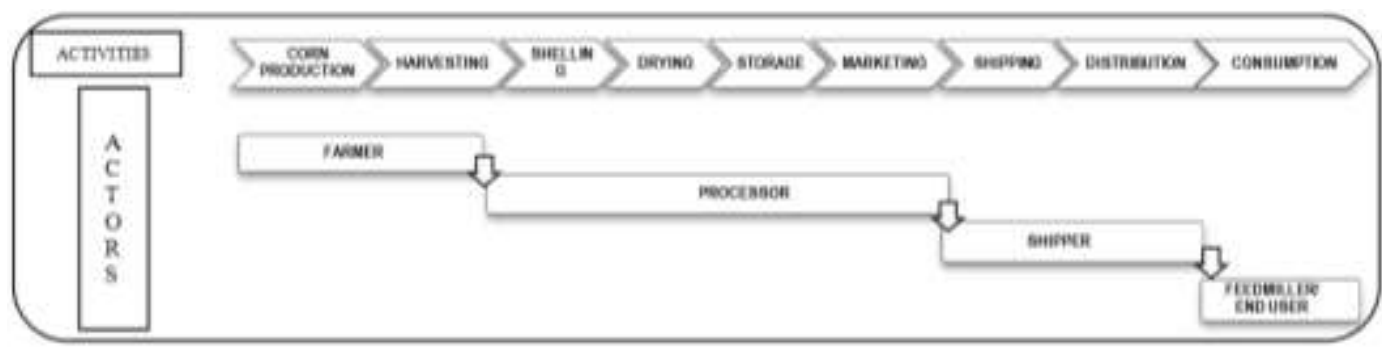

Source: Calica and Eleria, 2013 
Figure 2. Yellow corn grain value chain activities and key actors' role, bulk handling system, Mindanao to Manila and Cebu, 2012

Table 3 implies that farmers in the chain had complete trust on the traders whom they dealt personally while some trust on the processors and feedmillers who had indirect connection with each other regarding their product. Aside from the established credit tie-up with traders of farmers they were also the source of information on the quality requirement of the product. Traders, on the other hand, had some trust with all the actors in the chain perhaps because of the risk they were taking on the money they invested. Thus, they could not completely trust them. Processors /integrators had complete trust on traders not only because they personally dealt with them but they were the direct link from the source. Meanwhile, trust of distributors and feedmillers to each other was reciprocated because they were dependent to each other regarding on the supply of the commodity.

Whereas, in the bulk handing system, though farmers and processor/shippers in the chain had constant communication on the volume and price of corn grains during marketing, they rate themselves with some trust. This maybe because processor/shippers dealt with several farmers to accumulate stocks same as the farmer who could choose whom to sell his produce. Thus, they do not fully trust each other. However, though the feedmiller had his complete trust on the processor and shipper, the former who supplied the corn grains for his feed formulation had only some trust on him because they were not directly doing business with each other.

Table 3. Matrix for the level of trust of the different key actors, traditional and bulk handling systems, 2012

\begin{tabular}{|c|c|c|c|c|c|c|}
\hline KEY ACTORS & FARMER & TRADER & $\begin{array}{l}\text { PROCESSOR/ } \\
\text { INTEGRATOR }\end{array}$ & SHIPPER & DISTRIBUTOR & $\begin{array}{c}\text { FEEDMILLER } \\
\text { END USER }\end{array}$ \\
\hline \multicolumn{7}{|c|}{ TRADITIONAL SYSTEM } \\
\hline Farmer & 0 & 4 & 3 & 3 & 3 & 4 \\
\hline Trader & 3 & 0 & 3 & 3 & 3 & 3 \\
\hline Processor/Integrator & 3 & 4 & 0 & 3 & 3 & 3 \\
\hline Shipper & 2 & 3 & 3 & 0 & 3 & 4 \\
\hline Distributor & 2 & 3 & 3 & 3 & 0 & 4 \\
\hline Feedmiller & 2 & 2 & 4 & 4 & 4 & 0 \\
\hline \multicolumn{7}{|c|}{ BULK HANDLING SYSTEM } \\
\hline Farmer & 0 & - & 3 & 3 & - & 2 \\
\hline Processor & 3 & - & 0 & 3 & - & 3 \\
\hline Shipper/Distributor & 2 & - & 3 & 0 & - & 4 \\
\hline Feedmiller & 2 & - & 4 & 4 & - & 0 \\
\hline
\end{tabular}

Note: Complete trust- 4; Some trust-3; Little trust-2; No trust-1

\section{Conclusion and Policy Implications}

In the traditional method, farmers were engaged in all the activities starting from harvesting to marketing with informal agreements and had no enough knowledge on the quality requirements of the end consumers resulting to high marketing costs. Only the distributor and the feedmiller had a formal agreement among the actors in the chain.

Farmers in the bulk handling system were engaged in the production activity but received lower price for their produce than the traditional method but they would be better-off if they concentrated more on producing corn by planting two to three times a year.

Different actors involved in both chains have yet to have complete trust with each other to lessen the marketing costs. The frequent exchange of information and transparency of information creates trust in buyer-supplier relationships in the value chain thereby producing good quality corn.

For the farmers to adopt the bulk handling system, policymakers should provide the irrigation system needed by the farmers in planting three times in a year. The government should continue to explore potentials in the industry and link this program both to the local and international market. Lastly, aggressive promotion through trainings, publications and other media forms on the adoption of bulk handling system for the corn industry must be implemented. 


\section{Acknowledgment}

The authors would like to thank the Philippine Center for Postharvest Development and Mechanization (PHilMech) and the Agricultural Training Institute (ATI) of the Department of Agriculture of the Philippines for funding the study and Ms. Mary Joy D. Paico for gathering the data.

\section{References}

[1] Akerlof, George A. (1970). 'The Market for 'Lemons': Quality Uncertainty and the Market Mechanism". Quarterly Journal of Economics. The MIT Press. 84 (3): 488500. doi:10.2307/1879431. JSTOR 1879431.

[2] Calica, G.B. and N. L. Eleria. 2013. Economic Analysis on the bulk handling system of Mindanao corn grains to Manila and Cebu, Philippines, Journal of International Society of Southeast Asian Agricultural Sciences (J ISSAAS), Tokyo Japan, Vol. 20 Number 1, 1-15.

[3] Chen, Y. 2000. Promises, trusts and contracts, The Journal of Law, Economics and Organizations, 16 (1)

[4] Chiles, T. and McMackin, J. 1996. Integrating variable risk preferences, trust and transaction cost economics, Academy of Management Review 21 (1)

[5] De Luna, E.M. 2012. Corn industry development roadmap 2011-2017, A paper presented during the $8^{\text {th }}$ Philippine National Corn Congress, Waterfront, Insular Hotel, Davao City, Philippines, 25-28 of September 2012.

[6] Krugman, Paul (2009). The Return of Depression Economics and the Crisis of 2008. W.W. Norton Company Limited. ISBN 978-0-393-07101-6.

[7] Lantican, F.A. 2009. Grains supply chain. Paper presented during the 6th National Grains Postproduction Conference on November 25, 2009, Dauis, Bohol, Philippines

[8] Springer-Heinze, A. 2005. Shaping value chains for development-practice experiences. The global food and product chains - dynamics, innovations, conflicts, strategies, Stuttgart-Hohenheim, Germany, Deutscher, Tropentag

[9] Svensson G. 2005. Mutual and interactive trust in business dyads: condition and process, European Business Review 17 (5), 411-427.

[10] UNIDO. 2009. Agro-value chain analysis and development. The UNIDO Approach. A staff working paper, UNIDO, Vienna 